\title{
"Kesaktianmu” an Expression of Language Beauty with the Content of Infidelity in a Popular Love Song Study of Language Creativity and Sexism
}

\author{
Dewi Kusumaningsih \\ Veteran Bangun Nusantara University \\ Postgraduate Program, Sebelas Maret University \\ dewikusumaningsih71@gmail.com \\ Djatmika \\ Postgraduate Program, Sebelas Maret University
}

\author{
Riyadi Santosa \\ Postgraduate Program, Sebelas Maret University \\ D. Edi Subroto \\ Postgraduate Program, Sebelas Maret University
}

\begin{abstract}
The objective of this article is to show that (1) various types of lingual forms containing infidelity are written with beautiful dictions as a result of the writer's language creativity and (2) all lingual forms used in the song lyrics kesaktianmu (Your Spiritual Power) possess a sexism nuance. This present research is the resultsof the study of a text, namely song lyrics with the title of kesaktianmu popularized by a band group "Winner". The data collection methods adopted were listening, reading and recording. The research results were as follows. 1) There were many lingual forms, which are implicitly or explicitly written in words, phrases, clauses or sentences with infidelity content. Most of them are well and beautifully rhymed aimed at hiding negative lexical meanings (infidelity). 2) The fact of the choice of the lingual forms in the song lyrics showed the existence of inferior position of women experience as the objects or the receivers of men's activities. The lingual forms starting fromclithics, pronouns, verbs and adverbs show the evidence of the existence of sexism.
\end{abstract}

Keywords: expression, beauty, song, language creativity, sexism.

\section{INTRODUCTION}

Language expression as a form of communication maybe shown in various media, either oral or written media. The aim of communication between speakers and listeners using this language expression may also appear in songs. The writers of song lyrics present ideas by expressing all forms of either their experiences or their empathy to their environment. The writer's feelings are reflected in song lyrics.

The lyrics of a song often show the results of the writer's language creativity. A recent research showed that a popular song is a specifically artistic form, which is imbued with its own language. As a result, it demands a specific technique of analysis, representation, and specimen of classification[1], [2].This social language creativity emerges in various parts of a song structure with certain objectives. These objectives must be influenced by socio-cultural aspects, which develop and follow various elements of life in the society. [3], [4]The main concern in this study of language creativity is on the term of creativity itself as a real key word in daily life. In this present research, language is used as a form of creativity, which intentionally raises beautiful forms. The song lyrics of kesaktianmu are purposely hidden from the context of infidelity.

Infidel is an adjective that means (1) like to hide something for one's own interest; do not say something frankly; insincere; unfaithful; disloyalty; (2) like to use money illegally; corrupt; and (3) like to do unfaithful or disloyal acts.

Infidel is a root word with the derivative form, infidelity, which also means corruption, disloyalty. (7) In line with the meaning of the word, the act of "hiding" something dealing with infidelity must happen. The content of meaning of the word "infidel" is negative in nature. Therefore, anything dealing with infidel or infidelity must be hidden, since it is contrary to the fairness of values prevailing in various fields of life concerning with the actor, the place, the event, the facility, and the behavior of the language.

All the things hidden finally will result in a basic characteristic of "creative." It means that infidelity is creatively packaged, so that it becomes vague or in other words, obscured.

Language creation dealing with the event of infidelity in marriage has much been studied and it is shown that unfaithfulness or disloyalty in marriage is socially correlated [8].

In language social creativity, it is said that a micro process that backgrounds language creativity is influenced by certain analyses of values in sociolinguistics. Spatial stratification and social communication relationship are parts of values in sociolinguistics that influence the process of the language social creativity. Speakers who are creative in arranging words to convey meanings will choose words that are not covered by the stocks of conventional vocabulary [3].

Sexist language is a language representing men and women unequally where members of one sexual group are considered higher in humanity, more dignified, and having more rights than those from another sexual group. A bias in 
language practices occurs. [5], [6]. This present article will be different from those described above.

This article specifically will discuss various expressions of beauty of lingual forms containing infidelity either explicitly or implicitly stated in a song with the title of Kesaktianmu (Your Spiritual Power) popularized by a band group, Winner. After all lingual forms are identified, various points of view of the emerged language creativity will be presented. The aspects of meanings are used to accompany the analysis of the existing lingual forms, and the elements and the prominence of language sexism are used by digging out the situational contexts.

\section{METHOD}

In this present research, a descriptive qualitative model was employed to understand a hidden or almost unknown cultural phenomena [7], [8]. The data of this research were all lingual units, starting from phonemes, words, phrases, clauses to sentences and idioms in the lyrical texts of the song Kesaktianmu as the data source. A contextual model analysis was employed to describe and conceptualize the cultural phenomena emerging from the linguistic phenomenon studied. The data were inductively analyzed. It starts from observing the data, then classifying them into some categories in the form of matrices or tables in order to know the patterns of the relationships among categories and to interpret them simultaneously in a complex fashion among the patterns, the theories, the supporting data, and the contexts. The last, find the cultural theme of the phenomena.[7]

This research was focused on the first problem, to describe various lingual forms containing written infidelity using beautiful dictions because of the writer's language creativity.

The focus on the second problem was concentrated on sexism language. The understanding of language and gender as the knife of the analysis was applied to describe and show whether the lyrics of the song Kesaktianmu contain a sexism nuance [9]. In the analysis, language is not a static system or does not possess a rigid rule. However, it adopts a system that is often adapted to the context of the object aimed, and the emerging linguistic forms are not in line with the common meanings.

A crucial point that always exists in analyzing a gender is a stereotype role between men and women, in a society where women serves men. This is brought into various elements of life and language.

\section{RESULT}

The song Kesaktianmu tells about an event that is experienced by a couple who is falling in love and who has made love. However, both of them have not married legally as a husband and wife. It can be seen from the language form emerged.

The creativity in using the lingual forms that contain implicit or explicit infidelity is found in Kesaktianmu song from the categories of pronouns, nouns, verbs and adverbs. The construction of beautiful phrases, clauses and sentences emerged from the lyrics of this song. The meaning of "beautiful "is used to express love; but implicit forms were used to "hide" the meaning of infidelity.

Pronouns found in the lyrics of the song kesaktianmu were $-k u$ (my), - $m u$ (your), -nya (her/his).

\begin{tabular}{lll}
\hline No. & Pronoun & \multicolumn{1}{c}{ Data } \\
\hline 1 & $-\mathrm{ku}$ & $\begin{array}{l}\text { Mulutku } \\
\text { Your mouth }\end{array}$ \\
\hline & my & $\begin{array}{l}\text { Matamu (your eyes), tubuhmu (your } \\
\text { body), kesaktianmu (your spiritual power), } \\
\text { cintamu (your love) }\end{array}$ \\
\hline 3 & your & $\begin{array}{l}\text { Rasanya } \\
\text { Her/his feeling }\end{array}$ \\
\hline 4 & Ker/his & $\begin{array}{l}\text { Kau tikam (You stabbed), kau berikan } \\
\text { (you gave) }\end{array}$ \\
\hline
\end{tabular}

The use of pronouns merely consisting of possessive pronouns -ku (my), mu (your), and -nya (her/his) shows that the actors were only two persons.

Nouns used in these lyrics all refer to human body (eyes, mouth, and body) and abstract nouns (feeling, sin). The writer intentionally made use of nouns that merely refer to human body and abstract nouns since the object that is discussed is human being, more specifically their intimate relationship related to infidelity. Feeling and sin are abstract nouns that accompany the activities done in infidelity.

All nouns used in the lyrics refer to the context of making love. A deeper meaning of making love may be seen from the construction of clauses presented in Table 2 below. Table. 2 Basic Verb and Concatenated Verb in the song lyrics.

\begin{tabular}{|c|c|c|c|}
\hline No. & Verb & $\begin{array}{c}\text { Concatenated } \\
\text { Verb }\end{array}$ & Clausa \\
\hline 1 & $\begin{array}{l}\text { Bungkam } \\
\text { silence }\end{array}$ & $\begin{array}{l}\text { Membungkam } \\
\text { Silenced }\end{array}$ & $\begin{array}{l}\text { Kesaktianmu membungkam } \\
\text { mulutku.... } \\
\text { Your spiritual power } \\
\text { silenced my mouth..... }\end{array}$ \\
\hline 2 & $\begin{array}{l}\text { Peluk } \\
\text { embrace }\end{array}$ & $\begin{array}{l}\text { Memeluk } \\
\text { embraced }\end{array}$ & $\begin{array}{l}\text { Peluk tubuhmu terangi } \\
\text { aku.... } \\
\text { Peluk tubuhmu terangi aku } \\
\text { The embrace of your body } \\
\text { illuminated me }\end{array}$ \\
\hline 3 & $\begin{array}{l}\text { Ulang } \\
\text { repeat }\end{array}$ & $\begin{array}{l}\text { Ulangi } \\
\text { repeat }\end{array}$ & $\begin{array}{l}\text { Ingin kuulangi dosa yang } \\
\text { terindah.... } \\
\text { I wanna repeat the most } \\
\text { beautiful sin }\end{array}$ \\
\hline 4 & $\begin{array}{l}\text { Tikam } \\
\text { stab }\end{array}$ & $\begin{array}{l}\text { Menikam } \\
\text { stabbed }\end{array}$ & $\begin{array}{l}\text { Kau tikam aku dengan } \\
\text { cintamu.... } \\
\text { You stabbed me with your } \\
\text { love }\end{array}$ \\
\hline
\end{tabular}

When the verbs used in the song lyrics are integrated verbs (memeluk (hugged), memberi (gave), mengulang (repeated), the effects of meanings which bring more feelings will not emerge. It is like in the phenomenon of making the headline in the journalistic language where the omission of prefix (me-) is made to make meanings to be more persuasive in nature for the readers 
Adverbs used in this song also seem to be very beautiful and have been adjusted to the context of this song. The adverbs found in the lyrics were di saat malam itu (in the night); di saat malam-malam gelap; menjadi lemah tak berdaya (become powerless); yang terindah; dengan cintamu (during the bark night); surga dunia (world paradise); di saat dingin malam itu(during the cold night)). From all the adverbs, it is known that the surrounding contexts of meanings are a dark, cold and impressive night with full of love and resignation as the implicit subject in the contexts of the words.

The sentences used in the lyrics of kesaktianmu song used single sentence structures, but the dictions are very good. There are elements of metaphors used to hide the facts, from the implicit into the explicit ones.

Tatap matamu membunuh aku di saat malam itu

The stare of your eyes killed me in the night

Kesaktianmu membungkam mulutku menjadi lemah tak berdaya

Your spiritual power silenced my mouth, makes me powerless

Ingin kuulangi dosa yang terindah yang pernah kita lakukan

I wanna repeat the most beautiful sin we have ever made

The example of the verse above shows the structure of a single sentence with metaphor as the nuclear of the linguistic style to hide meanings. Metaphors are certain vocabularies that tell as if they are real and able to do something. The essence is the direct comparison.

\section{(1) Tatap matamu membunuh aku di saat malam itu} The stare of your eyes killed me in the night

Tatap mata (The stare of eyes) is like "a sharp object that may be used to kill". The stare of the eyes is so sharp that it is able to kill human being (me).

(2) Peluk tubuhmu terangi aku di saat malam-malam gelap

The embrace of your body illuminated me in the dark night.

An object that may illuminate is the one that contains light and warmth in nature. Warmth as the topic finally is chosen, stated inpeluk(kan) tubuhmu (menghangatkan) terangi aku di malam-malam gelap (The embrace of your body illuminated me)means "the embrace of his darling warmed him every night when he met her.

(3) Kesaktianmu membungkam mulutku menjadi lemah takberdaya

Your spiritual power silenced my mouth, makes me powerless.
Something that may silence the mouth is tight hands, and finally they may make one out of breath. In this context, the mouth of the woman was silenced with the "spiritual power of his darling" or his darling's lips, so that the lyrics contain the meaning of "kissing".

(4) Ingin kuulangi dosa yang terindah yang pernah kita lakukan.

I wanna repeat the most beautiful sin we have ever made.

Sin is a bad thing that should be frightened by believers of a religion. The feeling of sin the song writer wanted to show is the activity of making love that should not be done by a couple (because they are an illegal couple) but this is liked very much by the actors. As a result, they want to repeat the activity although it is a sin.

This language fact is also seen in the song lyrics of kesaktianmu which is implicitly stated, and it is the result of the language creativity of the writer.

All lingual forms used in the song lyrics kesaktianmu are sexism in its nuance.

As the opposite sex of man, woman is an interesting object of exploitation, not only in term of sexuality but also in stereotype where woman is a weak creature. The use of the figure of woman as the object of act has been shown in this song since the vocalist is woman. Since it is sung by a woman, the song lyrics are greatly suitable as the representation of an asymmetric figure (imbalanced representation) between woman and man [10]. It said as language sexism or language and sexism. The main answer to the implicit intention of the song kesaktianmu in sexism way is woman as the object of man's act who always plays her feelings. She is someone who is powerless who accepts a man's act. She cannot start every act with her own initiative because of her position as a secret lover.

The representation of the evidence of the sexism above emerges from various lingual forms of the song lyrics.

Kau tikam aku dengan cintamu

You stabbed me with your love

Dan rasanya manis sekali

And it felt very nice

Kau berikan aku surga dunia

You gave me a world paradise

Dan rasa ingin kuulangi

And I wanna repeat it again

The two verses of the song lyrics show the existence of sexism in language. There is an aspect of meaning of "accept" from the woman as stated in the song lyric " "kau tikam aku dengan cintamu (You stabbed me with your love)". It serves the meaning of the domination of man over woman. There are also many uses of personal pronouns (-mu; $k u-)$ (your, my) as an asymmetric form of gender emerged. The pronoun (- 
$m u$ )serves as the substitute of her man/lover who greatly dominates woman with the personal pronoun $(k u-)$.

\section{CONCLUSION}

The first problem about the lingual form used in the song lyrics kesaktianmu is the form of the beautiful language creativity the writer has created. The language forms used as the product of the writer's language creativity emerge either explicitly or implicitly. A social language creativity may be supported by new media that enable the owners of the problem to contribute to frame and solve the problem. The new media should be planned from a meta-design perspective by creating an environment where the stakeholders may act as the designers instead of only being consumers.

Researches on language and stereotype have been focused on the ways where the stereotype is expressed in language to represent how a stereotype model with a richer phenomenology may give us a better understanding of the phenomenon.

Sexism in language is a social problem, but it will not become a problem as long as the understanding of the concept of sexism in human life is minimized.

\section{REFERENCES}

[1] R. De Santis and R. F. De Souza, "Classifying popular songs: Possibilities and challenges," Knowl. Organ., 2014.
[2] M. Howlett, Song Means: Analysing And Interpreting Recorded Popular Song. 2014.

[3] Y. Nishihara, Y. Takahashi, and Y. Ohsawa, "Discourse analysis of communication generating social creativity," in Lecture Notes in Computer Science (including subseries Lecture Notes in Artificial Intelligence and Lecture Notes in Bioinformatics), 2009.

[4] J. Swann and A. Deumert, "Sociolinguistics and language creativity," Language Sciences. 2017.

[5] S. Mills, "Language and sexism," Lang. Sexism, vol. XXXIV, no. 2, pp. 1-178, 2008.

[6] C. Omar Sharif, "Sexism and Variations in the Use of Language," Int. J. Adv. Res, vol. 5, no. 12, pp. 11361144, 2017.

[7] R. Santosa, Metode Penelitian Kualitatif Kebahasaan. Surkakarta: UNS Press, 2017.

[8] D. E. Subroto, Pengantar Metode Linguistik Struktural, Pertama. Surakarta: UNS Press, 1992.

[9] L. \& S. W. Thomas, Bahasa, Masyarakat \& Kekuasaan, 1st ed., vol. 1. Yogyakarta: Pustaka Pelajar, 2007. 